\title{
On patent legislation, patent enforcement and economic growth: empirical evidence from developed and developing countries
}

\author{
Nikolaos Papageorgiadis \\ University of Liverpool Management School, \\ University of Liverpool, \\ Chatham Building, \\ Liverpool, L69 7ZH, UK \\ Email: n.papageorgiadis@liverpool.ac.uk
}

\section{Constantinos Alexiou* and Joseph G. Nellis}

School of Management,

Cranfield University,

Cranfield, Bedford, MK43 0AL, UK

Fax: +44 (0)1234-751806

Email: constantinos.alexiou@cranfield.ac.uk

Email: j.g.nellis@cranfield.ac.uk

*Corresponding author

\begin{abstract}
This study investigates the long-term effects of national patent legislation and enforcement systems on the economic development of 42 countries. The econometric methodology that has been adopted involves the estimation of three different models, namely, the pooled, the fixed effects and the random effects models whilst the specification of the economic development regressions is a variant of the standard growth specifications encountered in relevant studies. The empirical analysis is conducted in the context of the time period following the imposition of trade-related aspects of intellectual property rights (TRIPs). The results show that the extension and strengthening of patent legislation resulting from TRIPs have had a negative impact on economic development. In contrast, stronger levels of patent enforcement have had a positive effect overall and particularly for developing economies while negative for developed economies.
\end{abstract}

Keywords: patent legislation; patent enforcement; TRIPs; economic growth.

Reference to this paper should be made as follows: Papageorgiadis, N., Alexiou, C. and Nellis, J.G. (2016) 'On patent legislation, patent enforcement and economic growth: empirical evidence from developed and developing countries', Global Business and Economics Review, Vol. 18, No. 6, pp.623-641.

Biographical notes: Nikolaos Papageorgiadis is a Lecturer in International Business. His research focuses on the differences between national intellectual property (IP) protection and enforcement systems and their effect on the international business strategy of firms. At the country level, He investigates the role of IP protection and enforcement in explaining innovation, trade and investment and economic growth. At the industry/firm level, He researches the

Copyright (C) 2016 Inderscience Enterprises Ltd. 
effect of IP on MNE/SME international business strategies, innovation, knowledge transfer and firm performance. He has international experience in both business and academia. He is an Associated Researcher at the Department of Business Studies of Uppsala University (Sweden), where he was previously a postdoctoral researcher.

Constantinos Alexiou is a Reader in Economics at Cranfield School of Management where he delivers business related courses across the full range of the School's postgraduate and post-experience executive management programs. The main focus of his research revolves around macroeconomic policy, post Keynesian economics, determinants of bank profitability, financial sector reform in transition economies, the role of institutions in economic development, public deficit and economic growth, intellectual property rights etc. He is a frequent contributor to many international conferences and has produced papers published in leading international economic/business journals such as the Journal of World Business, Journal of Post Keynesian Economics, International Review of Applied Economics, International Business Review, Contributions to Political Economy, International Journal of Social Economics, etc.

Joseph G. Nellis is the Director of Cranfield School of Management. He has published 18 research and subject-based books and over 200 academic and practitioner journal articles. His research encompasses analysis of business developments in a changing world in terms of the macro-economy, the role of government, the impact of technology, societal and demographic trends. He is a frequent contributor to a wide range of national and international conferences and is a consultant to a number of UK and international companies in the areas of strategy and business environmental analysis, strategy formulation and management development. He has also acted as a consultant to several central government departments and public sector organisations.

\section{Introduction}

In terms of supporting economic development, should governments simply focus on the mere existence of patent legislation ('law on the books') or the degree of enforcement of this legislation ('law in action')? ${ }^{1}$ The debate over the effect of strengthening patent legislation and enforcement systems on the economic growth of developed and developing countries is now more topical than ever. Stronger patent legislation and enforcement can benefit patent-owning firms by enabling them to appropriate the economic returns from their investments in intangibles, such as on research and development (R\&D) activities (Ceccagnoli, 2006; Kumar, 1996; Teece, 1986).

Legislation that strengthens patent protection may increase litigation conflicts between firms operating in the same industries and, as a result, limit investment within an industry and discourage entrepreneurial activities by incumbent and prospective (Mazzoleni and Nelson, 1998). In so doing, policy makers are regularly accused of serving the interests of powerful multinational enterprises (MNEs) at the expense of economic development, civil rights and prosperity (Maskus, 2000; Stiglitz, 2008). Is it therefore sensible and appropriate for governments to push for stronger patent legislation and enforcement whilst their associated effects on economic development and growth are uncertain and highly debatable? 
Previous studies that have investigated the role of patent protection regulations on economic development and growth have analysed the years immediately after the signing of the TRIPs agreement (up to 1998) with only the study by Kim et al. (2012) reporting quinquennial evidence up to the year 2003. The results generally suggest a positive effect on economic development resulting from a strengthening of the levels of patent legislation (Falvey et al., 2006; Gould and Gruben, 1996; Schneider, 2005; Thompson and Rushing, 1996). However, when investigating the role of stronger patent legislation on the economic growth of developed and developing countries separately, the results become inconclusive (Kim et al., 2012; Schneider, 2005). Importantly, two decades after the TRIPs agreement, there is only limited evidence regarding the effect of strengthening patent legislation on the economic development of countries over time and any evidence that does exist is inconclusive. In as much as the relationship can be positive, it could also be negative or insignificant. Furthermore, given the changing global landscape in recent years, it is imperative that the impact of patent enforcement on economic development and growth is also appreciated since no evidence exists to date (Arora, 2009).

This paper makes two novel contributions to the literature and current debate. First, we empirically investigate the longer-term effects of the TRIPs implementation on developing and developed countries, utilising a 14-year annual panel dataset. ${ }^{2}$ This allows us to investigate the effects of strengthening patent legislation levels on economic development during a timeframe when the TRIPs policies were implemented. This is a significant contribution since existing studies in the literature have mainly captured the pre-TRIPs or the first post-TRIPs years. We find that the strengthened levels of patent legislation and at times the over-strengthening of patent legislation have a negative effect on the economic development of countries. This finding challenges the results of previous studies but confirms the early conceptual work that was in full swing after TRIPs, which questioned the outcome of the all-embracing strengthening of patent legislation across the globe (Maskus, 2000; Mazzoleni and Nelson, 1998).

Secondly, this study examines for the first time, the effect of the enforcement aspect of the patent system on the economic development of countries. While patent enforcement is a significant component of the patent system, its effect on economic development has not been studied to date, mainly due to lack of available data providing a measure for patent enforcement (Arora, 2009; Papageorgiadis et al., 2014). In this study, we overcome the data availability problems by incorporating in our analysis a new index developed by Papageorgiadis et al. (2014) which accounts for the extent of patent enforcement. We find that strong patent enforcement has a positive effect on the economic development of countries generally and, most importantly, this effect is highly significant in the context of developing countries. In contrast, the effect of patent enforcement on developed economies is negative. This negative effect is perhaps not surprising given the escalation of patent litigation and enforcement cases within and between different industries and across a number of developed countries in recent years (Hall and Harhoff, 2012; Ziedonis, 2003). In summary, this paper is aimed at addressing the following critical question: Does the very existence of patent legislation support economic development or is it the degree of patent legislation enforcement that is the key driving force for economic development?

The rest of the paper is organised as follows. Section 2 summarises the background and the existing literature on the rationale of patent protection in relation to existing evidence on economic development. Section 3 sets out the methodological framework 
used for the empirical investigation while Section 4 presents as well as links the results obtained to the existing evidence. The final section provides concluding remarks.

\section{Theoretical background}

Patent rights relate to the legal protection provided by countries to creators (both individuals and legal entities such as firms) of novel inventions relating to a product or a process, typically for a 20 year time period (WIPO, 2014). Rights over patents are granted by countries within their jurisdictions (and are shaped by international concordats) for two reasons:

1 to provide legal protection to the moral and economic rights of creators and the rights of the public in general to access those creations

2 to promote creativity and innovation (WIPO, 2014).

Creators and owners of intangible assets are granted the right in law to determine who can and cannot use their creations (providing that appropriate fees, if applicable, are paid to the patent-owner). It is important to recognise that a patent is not a 'monopoly' right as such but rather, an exclusionary right which may be granted or not. In simple terms, a patent owner is not given the statutory right to commercially exploit anything but instead is allowed to prevent (or exclude) others from doing so.

The patent system is comprised of two components,

a the patent legislation

b the enforcement related aspects of the legislation in practice (Papageorgiadis et al., 2014; Yang and Sonmez, 2013).

The existence of legal protection is generally expected to cover a broad spectrum of where patents can be allocated such as granting patents for inventions relating to pharmaceutical, chemical, agricultural and other products or processes (Ginarte and Park, 1997). Patent legislation is also expected to include provisions for strict remedies when patent infringement takes place. This is because the patent system and its benefits for countries and firms can only be effective when compliance with the law is evident and ensured within a jurisdiction. While broadening and strengthening patent protection is considered beneficial, it may also escalate litigation conflicts within a country and increase the costs that firms face when operating in a market (Mazzoleni and Nelson, 1998). Such conflicts will also increase the barriers to entry in the industry, deterring new or existing firms to compete in the market (Mazzoleni and Nelson, 1998).

Overall, the landscape of IP systems internationally and particularly the one for the patent system has changed significantly since the introduction of TRIPs (see UNCTAD, 1996; WTO, 2013). The wide differences evidenced in the minimum standards of patent legislation before the TRIPs agreement have, by and large, been eradicated since most countries have fully implemented the requirements set by TRIPS (Taubman et al., 2012). Differences in terms of patent legislation are still apparent, particularly the ones regarding even stronger protection offered by a number of developed countries (Reichman and Dreyfuss, 2007). However, the basic minimum standards of patent legislation are in place enabling patent owners to register and seek protection for their 
patent rights in both developed and developing countries. In contrast, the patent enforcement landscape is still in a state of flux with wide differences being evident across countries (Arora, 2009; Papageorgiadis et al., 2014).

By signing the TRIPs agreement, the signatory parties of the treaty inadvertently created an experiment, where a large number of countries simultaneously agreed to accelerate the introduction of stronger standards for IP protection - despite the fact that some countries (developing) would not have been expected to adopt such measures independently (Maskus, 2000). This is because by the year 1994, the level of IP protection boasted by a particular country was very much dependent on its nation's income and technological capabilities. The lower the national income and technological capability, the lower the legal protection of IP offered by the country in question (Maskus, 2000). This suggests that, in general terms, developed countries have tended to offer stronger levels of IP protection than developing.

A number of studies have examined the effect of the very existence of patent legislation on economic development for the years prior to the TRIPs agreement. Studies focusing on the 1960-1994 period found that 'stronger' IP legislation has a significant effect on economic growth (Falvey et al., 2006; Gould and Gruben, 1996; Schneider, 2005; Thompson and Rushing, 1996). 'Stronger' IP legislation is defined on the basis of the scope and depth of the patent legislation (for full details of the methodology see Park, 2008). The results of these studies are consistent and significant across the different datasets studied, providing strong evidence towards the potential benefits of the TRIPs agreement in different years. Furthermore, Gould and Gruben (1996) find the positive effects of IP legislation to be stronger for more open than relatively closed economies. However, there is significant variation in the results when the datasets are divided into two groups, one for developed and one for developing countries. While Schneider (2005) finds a positive and significant relationship between IP legislation and economic growth for 47 countries, the strength of the relationship does not hold when the dataset is divided into developed and developing countries. IP is also found to have a positive effect on economic growth for high and low income countries, but no significant effect on middle income countries (Falvey et al., 2006). In addition, some studies looking at the same period find the existence of IP legislation to have a positive indirect effect on economic growth, by having a moderating effect on other variables. This was the case for the study by Thompson and Rushing (1999) who found that patent protection has a positive and significant relationship with total factor productivity, which in turn positively stimulates economic growth. This was the case only for developed economies, since the results for all other tests found an insignificant relationship. Furthermore, even though Park and Ginarte (1997) do not find IP legislation to directly stimulate economic growth, they find it to have a positive effect when combined with R\&D activities in developed but not in developing countries.

While the results from the literature prior to the signing and implementation of TRIPs are in relative agreement relating to the positive effects of the existence of IP legislation, there is only one study that uses more contemporary data. Kim et al. (2012) use a dataset for the years 1975-2003 (five year intervals) and find patent legislation to have a positive effect on economic growth in developed countries; however it has no effect on the growth of middle-low income countries. This result is in agreement with the previous literature and points towards the positive trajectory of strengthening IP legislation leading to economic growth. However, this effect has not been tested and confirmed by other 
studies. Importantly, many developing countries have fully or partially fulfilled the requirements of the TRIPS agreement by the year 2005 .

In this section we have reviewed the literature on patent legislation in the context of pre and post-TRIPs agreement. There is no consensus in the literature concerning the positive or negative effect on economic development and growth arising from the mere existence of patent legislation (based on the Park, 2008 index methodology). We now turn in the following section to investigate the impact of patent legislation on economic development still further by providing a more in-depth analysis of the implications of patent legislation from two perspectives:

a the mere existence of legislation (measured by Park, 2008)

b the enforcement of patent legislation (measured by Papageorgiadis et al., 2014).

\section{Hypotheses, methodology and modelling framework}

\subsection{Hypotheses}

As noted above, it is important to identify the effect that strengthening levels of patent legislation have on economic development. Here we explore this possible linkage by testing the following two hypotheses. Our first hypothesis relates to the mere existence of patent legislation and is expressed as follows:

$\mathrm{H}_{1}$ Stronger levels of patent legislation in the period after the TRIPs agreement have had a positive effect on the economic development of both developed and developing countries.

The rationale for stronger actual enforcement of patents is in line with the reasoning that led to the adoption of strengthening patent legislation measures put forward by TRIPs. Our second hypothesis investigates the impact of patent enforcement as follows:

$\mathrm{H}_{2}$ Stronger levels of patent enforcement have had a positive effect on the economic development of both developed and developing countries.

\subsection{Methodology}

For the empirical investigation we develop a model - consisting of a dependent variable and a string of control variables - which is formulated and estimated for 42 countries over the period 1998-2011. The dataset used in the empirical investigation comprises both developed and developing economies. We initially provide estimates for the entire pool of countries in the dataset and then, on the basis of the size of their economies, we proceed with the estimation of models for two different clusters, i.e., developed and developing countries.

In general, the model falls within the broad theoretical framework of economic development and growth determination but this time the emphasis is on the impact that the mere existence of patent legislation (based on Park, 2008) as well as on the extent of patent enforcement (based on Papageorgiadis et al., 2014) may have on economic development. 
The 42 countries investigated are shown in Table 1 below, grouped according to developing (15) and developed (27) countries, as defined by the World Bank (2009). ${ }^{3}$

Table 1 Countries included in the analysis

\begin{tabular}{llllll}
\hline Developing countries & & & Developed countries \\
\hline 1 & Argentina & 1 & Australia & 16 & Japan \\
2 & Brazil & 2 & Austria & 17 & Korea (South) \\
3 & China & 3 & Belgium & 18 & Netherlands \\
4 & Colombia & 4 & Canada & 19 & New Zealand \\
5 & Hungary & 5 & Chile & 20 & Norway \\
6 & India & 6 & Czech Republic & 21 & Poland \\
7 & Indonesia & 7 & Denmark & 22 & Portugal \\
8 & Malaysia & 8 & Finland & 23 & Singapore \\
9 & Mexico & 9 & France & 24 & Spain \\
10 & Philippines & 10 & Germany & 25 & Sweden \\
11 & Russia & 11 & Greece & 26 & Switzerland \\
12 & South Africa & 12 & Hong Kong & 27 & UK \\
13 & Thailand & 13 & Ireland & & \\
14 & Turkey & 14 & Israel & & \\
15 & Venezuela & 15 & Italy & & \\
\hline
\end{tabular}

\subsubsection{The variables}

The selection of variables used in this study is in line with the existing literature on economic growth and development theory (see for instance Li and Liu, 2005; Borensztein et al., 1998; Barro, 1991). More specifically, in the majority of the research studies published on the determinants of economic development and growth the dependent variable is proxied by the inclusion of GDP per capita growth and therefore this is the dependent variable in our models (Falvey et al., 2006; Kim et al., 2012; Park and Ginarte, 1997; Schneider, 2005; Thompson and Rushing, 1996).

As we stressed previously the focal point of this study is to measure the impact of patent legislation strength in terms of its mere existence, as well as the effect of patent enforcement on economic development. To do this, we incorporate into our models the Park (2008) index (of the existence of patent legislation) and the Papageorgiadis et al. (2014) index (of patent enforcement) respectively.

\subsubsection{Existence of patent legislation index}

The Park (2008) index was first published by Ginarte and Park (1997) and provided quinquennial scores of patent legislation strength for 110 countries over the period 1960-1990. It was subsequently updated by Park (2008) quinquennially up to and including the year 2005 with data on 122 countries. According to Park (2008, p.761) "this index was designed to provide an indicator of the strength of patent protection, not the quality of patent systems". The index therefore measures patent legislation strength in 
terms of the existence (or not) of a number of different laws in the legal systems of countries. Twenty laws or legal provisions are considered for the quantification of the index, grouped into five categories, namely:

- patent coverage

- membership of international treaties

- $\quad$ enforcement mechanisms

- restrictions on patent rights

- duration of patent protection.

The summated value of scores under each of the five categories comprises the final index measured along a scale of $0-5$, with higher values signifying stronger levels of patent legislation.

\subsubsection{Strength of patent enforcement index}

The Papageorgiadis et al. (2014) composite index measures the strength of national patent systems by focusing on the effectiveness of enforcement practices in conjunction with the overall administrative functioning of the system. This new index follows the theoretical underpinnings of transaction cost theory and estimates the level of transaction costs that patent owning firms face when engaging with a national patent system. A country's score is the aggregate of three transaction costs constructs, namely:

- $\quad$ servicing costs

- $\quad$ property rights protection costs

- monitoring costs.

The higher the score of a country, the easier it is for a firm to enforce its patent rights and vice versa.

\subsubsection{Other independent variables}

We incorporate six control variables in our model which are used widely in the economic development and growth literature, namely:

a gross capital formation

b government stability

c FDI flows

d human capital

e inflation rate

f investments in R\&D (Kim et al., 2012; Park and Ginarte, 1997; Sala-i-Martin, 1997).

Gross capital formation is commonly found to be a significant parameter in the determination of growth in the majority of economic development and growth models since an increase in the capital stock is needed to promote economic activity, which in 
turn stimulates economic growth (Barro, 2003; Mankiw et al., 1992; Sala-i-Martin, 1997; World Bank, 1989). In our model we use gross fixed capital formation as a percentage of GDP and therefore expect this variable to be positively related to growth. Government stability is commonly expected to provide the necessary supporting conditions that enable economic growth (Barro, 1991, 2003). We use the government stability data developed by the PRS Group (2013) and provided in the international country risk guide (ICRG) and anticipate higher levels of political stability to have a positive relationship with economic growth. FDI flows are included in our model since they are widely expected to generate positive spillover effects for the host economies and therefore positively affect economic growth (Borensztein et al., 1998; Li and Liu, 2005; Lipsey, 2002). In order to control for the anticipated positive effects that high quality human capital can have on the economic growth of a country (especially for developing countries), we use data on national school enrolment in tertiary education in our model and expect this variable to bear a positive sign (Awokuse and Yin, 2010; Gould and Grouben, 1996; Mankiw et al., 1992). We also use the inflation rate as a proxy for the economic stability within a country and anticipate a negative relationship with economic growth (Barro, 2003). Finally, investments in $R \& D$ can positively affect economic growth. In our model, we use data on the number of $R \& D$ researchers per million population to account for $R \& D$ investments and anticipate a positive relationship with economic growth (Park \& Ginarte, 1997).

\subsection{Modelling framework}

This subsection considers the empirical determinants of economic development using a sample of 42 countries, covering a broad range of experience from developing to developed countries. The number of countries investigated is constrained by data availability relating to the patent legislation and enforcement indices. ${ }^{4}$

The econometric methodology that has been adopted involves the estimation of panel models along the lines suggested by Baltagi (2013). The empirical specification of the economic development regressions is a variant of the standard growth specifications encountered in relevant studies (see for instance Barro, 2003).

We start by using a general-to-specific approach on the basis of which we simplify an initial general model that adequately characterises the empirical evidence within our theoretical framework.

The dataset used spans the period 1998 to 2011, consisting of $\mathrm{N}$ cross-sectional units, denoted $i=1, \ldots, N$ observed at $T$ time periods, denoted $t=1, \ldots, T$. More specifically, $y$ is a $(T N \times 1)$ vector of endogenous variables, $x$ is a $(T N \times k)$ matrix of exogenous variables, which does not include a column of units for the constant term. In this context, we collated data for a cross section of 42 developed and developing countries $(N=42)$, over a period of 14 years $(T=14)$. In passing, it should be stressed that after estimating equations using the entire dataset, we then, on the basis of the size of the economies, split the dataset into two groups, thus generating a cluster with 15 developed countries and a cluster with 27 developing countries.

The generic linear econometric form of the model utilised can be expressed as follows:

$$
y_{i t}=\alpha_{i}+\beta_{i} x_{i t}+\varepsilon_{i t},
$$




$$
\varepsilon_{i t} \sim \text { i.i.d. }\left(0, \sigma_{i}^{2}\right)
$$

where $y_{i t}$ is the dependent variable, $\alpha_{i}$ is the intercept term, $\beta_{i}$ is a $k \times 1$ vector of parameters to be estimated by the explanatory variables, and $x_{i t}$ is a $1 \times k$ vector of observations on the explanatory variables, $t=1, \ldots, \mathrm{T}, i=1, \ldots, N$, and $\varepsilon_{i t}$ is a random term, assumed to satisfy the normal requirements.

We distinguish three cases of equation (1):

\subsubsection{The pooled model}

When both $\alpha$ and $\beta$ are common between regions, we get the pooled model:

$$
y=\imath \alpha+\beta X+\varepsilon,
$$

where $l$ is a $(T N \times 1)$ column vector of ones. For this simple model, the generalised least squares (GLS) estimator reduces to pooled ordinary least squares (OLS).

\subsubsection{The fixed effects model}

The fixed effects (or least squares dummy variables model, or within model) is based on the notion that differences across countries can be captured in differences in the constant term:

$$
y_{i t}=\alpha_{i}+\beta^{\prime} x_{i t}+\varepsilon_{i t},
$$

The fixed effects model is a reasonable approach when we can be confident that the differences between countries can be viewed as parametric shifts of the regression function. Equations (2) and (3) are restricted versions of the general model (1) while (2) is a restricted form of equation (3). Under the assumption that the $\varepsilon_{i t}$ are independently normally distributed over $i$ and $t$ with mean zero and variance $\sigma_{\varepsilon}^{2}, F$-statistics can be used to test the linear restrictions postulated by equations (2) and (3).

\subsubsection{The random effects model}

In the event when sampled cross sectional units are drawn from a large population, it may be more appropriate to use the random effects model (or variance components model), in which individual constant terms are randomly distributed across cross sectional units:

$$
y_{i t}=\alpha+\beta^{\prime} x_{i t}+\mu_{i}+\varepsilon_{i t},
$$

where $E\left(\mu_{i}=0\right), E\left(\mu_{i}^{2}\right)=\sigma_{\mu}^{2}, E\left(\mu_{i} \mu_{j}\right)=0$ for $i \neq j$, and $E\left(\varepsilon_{i t} \mu_{j}\right)=0$, for all $i, t$, and $j$. Thus $\mu_{i}$ is a random disturbance which characterises the $i^{\text {th }}$ observation and is constant through time; it can be regarded as a collection of factors that are specific to region $i$ and are not included in the regression. The above model can be estimated by GLS.

Given the preceding theoretical exposition in conjunction with equation (1) apart from the main determinants of growth, we primarily seek to isolate and effectively gauge the impact of two variables relating to the existence of patent legislation (using the Park, 2008 index) and patent enforcement strength (using the Papageorgiadis et al., 2014 index). In doing so, we estimate various specifications of model (1). The explicit form of the final model to be estimated is expressed as follows: 


$$
\begin{aligned}
g d p c c_{i t}= & a_{0}+a_{1} g c f_{i t}+a_{2} f d i_{i t}+a_{3} r d_{i t}+a_{4} h c_{i t}+a_{5} i n f_{i t}+a_{6} g v s_{i t} \\
& +a_{7} p l_{i t}+a_{8} p e_{i t}+\varepsilon_{i t} \\
\varepsilon_{i t}=v_{i}+u_{i t} &
\end{aligned}
$$

where $g d p p c$ is GDP per capita, $g c f$ denotes gross capital formation to GDP ratio, $f d i$ is foreign direct investment flows as percentage of GDP, $r d$ stands for research and development, $h c$ is human capital, inf is inflation rate, gvs denotes government stability, $p l$ is the Park (2008) index of the existence of patent legislation, pe is the Papageorgiadis et al. (2014) index of patent enforcement strength, $\varepsilon_{t}$ is the disturbance term, $v_{i}$ captures the unobserved country-specific effect while $u_{i t}$ is the idiosyncratic error. This is a one-way error component regression model, where $v_{i} \sim \operatorname{IIN}\left(0, \sigma^{2}\right)$ and independent of $u_{i t} \sim \operatorname{IIN}\left(0, \sigma^{2}\right)$. The natural logarithm of each variable was used. The definitions as well as the descriptive statistics of the variables are provided in Table 2.

Table 2 Definitions of variables and descriptive statistics

\begin{tabular}{llcccc}
\hline \multicolumn{2}{l}{ Variables } & Mean & S.D. & Max. & Min. \\
\hline gdpcc & GDP per capita growth (annual, \%) & 3.1 & 3.6 & 13.6 & -13.1 \\
$g c f$ & Gross fixed capital formation/GDP (\%) & 23.3 & 6.5 & 48.6 & 10.9 \\
$g v s$ & Government stability (ICRG, index 0-12) & 8.9 & 1.5 & 12 & 5.1 \\
$f d i$ & FDI net inflows (in \$bn) & 117.6 & 156.0 & 321.3 & 7.3 \\
$h c$ & Gross enrolment ratio (\%) & 52.11 & 20.54 & 103.87 & 6.19 \\
$i n f$ & Inflation rate (consumer price index, \% p.a.) & 8.3 & 11.9 & 85.7 & -4.1 \\
$r d$ & Researchers in R\&D per million of population. & 2555 & 1844 & 8007 & 49 \\
$p l$ & Patent legislation strength (Park, 2008, index 0-5) & 3.9 & 0.6 & 4.7 & 1.2 \\
$p e$ & Patent enforcement strength (Papageorgiadis et al., & 6.5 & 2.1 & 9.9 & 2.5 \\
& 2014, index 0-10) & & & & \\
\hline
\end{tabular}

Note: ${ }^{1}$ Gross enrolment ratio (GER): is the total enrolment in tertiary education regardless of age, expressed as a percentage of the total population of the five-year age group following on from secondary school leaving. GER can exceed $100 \%$ due to the inclusion of over-aged and under-aged students because of early or late school entrance and grade repetition (World Bank, 2014b).

Source: Data on patent legislation and patent enforcement were sourced directly from the published work of Park (2008) and Papageorgiadis et al. (2014) respectively. Government stability data originate from the international country risk guide (ICRG) developed by the PRS Group (2013). The World Bank open data website of the World Bank $(2014 \mathrm{c})$ was the source for the data for all other variables used in the estimation.

All estimated models were subjected to a series of rigorous testing for robustness. More specifically, the White heteroskedasticity consistent covariance estimator with ordinary least squares estimation was used to ensure that the standard errors are robust. Then the Durbin-Wu-Hausman (DWH) test for endogeneity was employed in an attempt to identify and effectively address potential limitations in the model (for a more comprehensive analysis on the application of the DWH test, see Davidson and MacKinnon, 1993). 
Additionally, the variance inflation factor (VIF) as well as the cross correlation matrix suggested that existing collinear relationships were kept to a minimum as the average VIF score was 3.6 when a common rule of thumb is that VIF scores higher that 10 may constitute a legitimate cause for concern (Kutner et al., 2004; O'Brien, 2007). ${ }^{5}$

\section{Results}

In this section we set out and discuss the results for the entire dataset as well as for the clusters of developed and developing countries separately. We estimate three different models, namely the pooled, fixed effects and random models. On the basis of the selection criteria (i.e., F-test, Hausman and LM tests), the model that turns out to be the most legitimate and therefore the one that the interpretation of the results will be based upon is the fixed effects model in all three different data sets respectively.

Table 3 provides the estimation results for the entire dataset. Similarly, Table 4 reports the estimation results for the cluster of the developed economies in the sample and Table 5 presents the findings of the regression models for the group of the developing economies.

Table 3 Growth regression estimates for entire dataset - with robust (HAC) standard errors (dependent variable: GDP per capita growth)

\begin{tabular}{|c|c|c|c|}
\hline \multicolumn{4}{|c|}{ All countries } \\
\hline Explanatory variables & $\begin{array}{c}\text { Pooled model } \\
\text { coefficient (std. error) }\end{array}$ & $\begin{array}{c}\text { Fixed effects } \\
\text { coefficient (std. error) }\end{array}$ & $\begin{array}{c}\text { Random effects } \\
\text { coefficient (std. error) }\end{array}$ \\
\hline $\mathrm{GCF}$ & $0.23(0.06)^{* * *}$ & $0.44(0.06)^{* * *}$ & $0.22(0.03)^{* * *}$ \\
\hline Government stability & $0.09(0.05)^{*}$ & $0.06(0.05)$ & $0.04(0.03)$ \\
\hline FDI & $0.02(0.01)^{* *}$ & $0.01(0.007)^{*}$ & $0.02(0.007)^{* * *}$ \\
\hline Human capital & $0.04(0.01)^{* *}$ & $0.09(0.05)^{* *}$ & $0.04(0.02)^{* *}$ \\
\hline inflation rate & $-0.02(0.008)^{*}$ & $-0.08(0.07)$ & $-0.01(0.01)$ \\
\hline $\mathrm{R} \& \mathrm{D}$ & $-0.0003(0.01)$ & $0.08(0.06)$ & $0.0003(0.01)$ \\
\hline Patent legislation & $-0.12(0.06)^{*}$ & $-0.08(0.007)^{*}$ & $0.08(0.05)^{*}$ \\
\hline Patent enforcement & $0.09(0.03)^{* * *}$ & $0.35(0.13)^{* * *}$ & $0.06(0.02) * * *$ \\
\hline Const. & $-0.87(0.14)^{* * *}$ & - & - \\
\hline $\mathrm{R}^{2}$ & 0.54 & 0.57 & 0.58 \\
\hline Hausman $\left(X^{2}\right)^{\mathrm{a}}$ & $54.85[0.00]$ & & \\
\hline F-test $(\mathrm{FE}=0)^{\mathrm{b}}$ & $1.510[0.04]$ & & \\
\hline Breusch-Pagan $^{c}$ & $2.58[0.107]$ & & \\
\hline
\end{tabular}

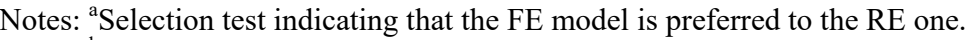

${ }^{\mathrm{b}}$ Tests the joint significance of the fixed effects estimates - FE is preferred to PM.

${ }^{\mathrm{c}} \mathrm{An} \mathrm{LM}$ test used in the selection between the PM and the RE model - PM is preferred.

$*, * *$ and $* * *$ denote significance at $10 \%, 5 \%$ and $1 \%$ level respectively; p-values are given in the square brackets. 
Table 4 Growth regression estimates for the group of developed economies in the cluster with robust (HAC) standard errors (dependent variable: GDP per capita growth)

\begin{tabular}{lccc}
\hline \multicolumn{4}{c}{ Developed } \\
\hline Explanatory variables & $\begin{array}{c}\text { Pooled model } \\
\text { coefficient (std. error) }\end{array}$ & $\begin{array}{c}\text { Fixed effects } \\
\text { coefficient (std. error) }\end{array}$ & $\begin{array}{c}\text { Random effects } \\
\text { coefficient (std. error) }\end{array}$ \\
\hline GCF & $0.11(0.015)$ & $0.23(0.09)^{* *}$ & $0.19(0.10)^{* *}$ \\
Government stability & $0.23(0.21)$ & $0.03(0.18)$ & $0.13(0.12)$ \\
FDI & $0.01(0.01)$ & $0.004(0.006)$ & $0.06(0.05)$ \\
Human capital & $0.07(0.04)^{*}$ & $0.13(0.06)^{* *}$ & $0.13(0.07)^{* *}$ \\
inflation rate & $0.02(0.01)^{*}$ & $-0.24(0.23)$ & $-0.19(0.16)$ \\
R\&D & $-0.05(0.005)$ & $0.01(0.02)$ & $0.08(0.06)$ \\
Patent legislation & $0.005(0.11)$ & $0.04(0.16)$ & $0.05(0.18)$ \\
Patent enforcement & $-0.009(0.04)$ & $-0.32(0.18)^{*}$ & $-0.36(0.16)^{* *}$ \\
Const. & $0.53(0.28)^{*}$ & - & - \\
$\mathrm{R}^{2}$ & 0.47 & 0.52 & 0.53 \\
\hline Hausman $\left(\mathrm{X}^{2}\right)^{\mathrm{a}}$ & $23.42[0.00]$ & & \\
F-test $(\mathrm{FE}=0)^{\mathrm{b}}$ & $19.65[0.00]$ & & \\
Breusch-Pagan & $31.60[0.00]$ & & \\
\hline
\end{tabular}

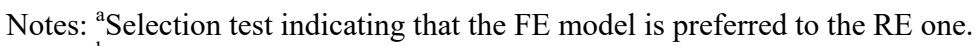

${ }^{\mathrm{b}}$ Tests the joint significance of the fixed effects estimates - FE is preferred to RE.

${ }^{\mathrm{c}} \mathrm{An}$ LM test used in the selection between the PM and the RE model - RE is preferred.

$*, * *$ and $* * *$ denote significance at $10 \%, 5 \%$ and $1 \%$ level respectively; p-values are given in the square brackets.

As shown in Table 3, the explanatory power of the most preferred model, i.e., the fixed effects model, reflected by the coefficient of determination $\mathrm{R}^{2}$, is satisfactory suggesting that $57 \%$ of the variation in the dependent variable is effectively explained by variations in the independent variables as a whole. The coefficients of patent legislation strength and patent enforcement strength are found to be statistically significant at the $10 \%$ and $1 \%$ levels of significance respectively - but it is worth commenting on the difference of the signs that the two variables bear. In particular, patent legislation strength as measured by the Park (2008) index is found to be negatively signed and moderately significant. This suggests that economic development is adversely affected by the strengthening of patent legislation.

This negative relationship is found to be moderately significant in the regressions covering the entire dataset but found to be insignificant for the split datasets based on the developed and developing countries alone. Therefore the results obtained for the entire dataset reject $\mathrm{H}_{1}$ since stronger levels of patent legislation in the period after the TRIPs agreement are found to have a negative effect on the economic growth and development of countries. This is a controversial but important finding. After the TRIPs agreement, the signatory countries reformed their statutory patent legislation provisions and strengthened them in order to boost competition and increase economic activity. The evidence suggests that the strengthening of patent legislation had a negative rather than a positive effect on the economic development of the reforming countries. While in the past countries adapting stronger legal protection of patents enjoyed higher levels of economic 
development, this is not at all evident in the post TRIPs era. In fact, stronger patent legislation is more likely to have a counterproductive effect on the economic growth of a country. This may be due to the sudden push for stronger levels of patent legislation across the board of all TRIPs signatory countries, when in the past countries strengthening their patent legislation differed from others and were able to attract and retain higher levels of economic activity. This result challenges the findings of earlier studies using data from the years before or immediately after the signing and implementation of the TRIPs agreement, which found stronger levels of patent protection to positively affect economic growth, especially for developed countries (Falvey et al., 2006; Kim et al., 2012; Thompson and Rushing, 1996; Schneider, 2005).

Table 5 Growth regression estimates for the group of developing economies in the cluster with robust (HAC) standard errors (dependent variable: GDP per capita growth)

\begin{tabular}{lccc}
\hline \multicolumn{4}{c}{ Developing } \\
\hline Explanatory variables & $\begin{array}{c}\text { Pooled model } \\
\text { coefficient (std. error) }\end{array}$ & $\begin{array}{c}\text { Fixed effects } \\
\text { coefficient (std. error) }\end{array}$ & $\begin{array}{c}\text { Random effects } \\
\text { coefficient (std. error) }\end{array}$ \\
\hline GCF & $0.24(0.08)^{* * *}$ & $0.51(0.10)^{* * *}$ & $0.24(0.08)^{* * *}$ \\
Government stability & $0.29(0.11)^{* * *}$ & $0.16(0.09)^{*}$ & $0.29(0.10)^{* * *}$ \\
FDI & $0.03(0.03)$ & $0.03(0.02)^{*}$ & $0.03(0.03)$ \\
Human capital & $0.08(0.04)^{*}$ & $0.05(0.07)$ & $1.14(0.15)^{* * *}$ \\
Inflation rate & $-0.01(0.02)$ & $-0.34(0.33)$ & $-0.62(0.60)$ \\
R\&D & $0.03(0.02)$ & $0.23(0.20)$ & $0.45(0.41)$ \\
Patent legislation & $0.29(0.14)^{* *}$ & $0.12(0.11)$ & $-0.29(0.14)^{* *}$ \\
Patent enforcement & $0.02(0.09)$ & $0.48(0.19)^{* *}$ & $0.02(0.09)$ \\
Const. & $-1.76(0.42)^{* * *}$ & - & - \\
$\mathrm{R}^{2}$ & 0.49 & 0.51 & 0.51 \\
\hline Hausman $\left(\mathrm{X}^{2}\right)^{\mathrm{a}}$ & $38.82[0.00]$ & & \\
F-test $(\mathrm{FE}=0)^{\mathrm{b}}$ & $14.52[0.00]$ & & \\
Breusch-Pagan & $60.612 .61[0.00]$ & & \\
\hline
\end{tabular}

Notes: ${ }^{\text {a}}$ Selection test indicating that the FE model is preferred to the RE one.

${ }^{\mathrm{b}}$ Tests the joint significance of the fixed effects estimates - FE is preferred to RE.

${ }^{\mathrm{c}} \mathrm{An}$ LM test used in the selection between the PM and the RE model - RE is preferred.

$*, * *$ and $* * *$ denote significance at $10 \%, 5 \%$ and $1 \%$ level respectively;

p-values are given in the square brackets.

However, our study confirms the findings of previous conceptual studies in terms of patent legislation having an insignificant effect on the economic development of developing countries. While the push for stronger patent legislation levels prior to TRIPs was justified and based on solid past evidence, the results of our study cast doubt on whether or not such an approach should be pursued further. This has important implications for policy makers as well as for business investment decisions. On the one hand, developing countries have no incentive to extend and adopt stronger levels of patent legislation since allocating time and resources on patent protection reforms will not increase the likelihood of achieving growth. In contrast, they can focus the time and resources allocated to reforms on other aspects of their institutions such as improving the 
quality and availability of human capital which is found to induce economic development. On the other hand, as the evidence of this study suggests that even if a developing country decides to invest its efforts on the strengthening of patent legislation, their reformed patent protection legislation is more likely to have a negative effect on economic growth. This is because the adoption of rigid and inflexible legislative frameworks may well discourage business activity and act as an impediment to economic growth. A more sensible policy recommendation therefore would be to modernise and simplify the existing, strong patent legislation framework so that it once again provides confidence and certainty to its users (Hargreaves, 2011).

In contrast, strengthening levels of patent enforcement are found to have a positive and highly significant relationship with the economic development regressions for the entire dataset. This relationship remains positive and significant when considering the developing countries' cluster dataset but turns into a moderately negative relationship for the developed economies' dataset. On the basis of the entire dataset and developing countries' cluster, we fail to reject the second hypothesis as we have clear evidence that stronger levels of patent enforcement do indeed positively influence the economic development of countries, especially developing ones. In contrast, we reject the second hypothesis with regards to the results for the dataset concerning the developed countries. These are significant findings as this is the first study that empirically tests the longer term effect of patent enforcement on economic development. As the patent systems of countries that are signatory to the TRIPs agreement have evolved and the level of patent legislation has been strengthened to a point where relative harmonisation is achieved across minimum patent protection regulations, the actual enforcement of these laws in practice becomes the crucial ingredient that enables or deters countries to achieve economic growth. Especially in a developing country context, strong levels of enforcement can reassure the patent owners that once their patent is granted, they can seek for and achieve effective enforcement in actual practice should that be required in the event that patent infringement occurs. However, the actual enforcement of rigid and inflexible legislative frameworks of developed countries may discourage business activity and act as an impediment to economic growth.

The results presented here clearly demonstrate that while previous studies in the literature have considered patent protection in terms of the mere existence of the law only, this paper provides strong evidence to suggest that the enforcement related aspects of the patent system are those which positively affect the economic development of countries. The importance of patent enforcement should be highlighted and included in the policy recommendations helping to stimulate economic growth in a country. We would argue that all countries, particularly developing ones, can potentially benefit from stronger levels of patent enforcement. This suggests that developing countries can embrace the policies towards the strengthening of patent enforcement that are currently under negotiation at an international level since these are expected to have a positive effect on their economic development. While the regression for the cluster of developed countries shows patent enforcement to have a moderately negative effect on economic development, this may be due to stronger levels of patent enforcement being applied to enforce highly stringent legislative frameworks as achieved by developed economies after the TRIPs agreement (Papageorgiadis et al., 2013, 2014). Developed economies that push for reforms to strengthen patent enforcement therefore need to also incorporate policies for the modernisation and simplification of patent legislation frameworks 
internationally, so that they can also positively affect (and not deter) their economic development progress.

As far as the emerging relationships between the dependent and the rest of the control variables are concerned, an inspection of the most preferred model (the fixed effects model) suggests that gross capital formation, human capital investment and FDI flows bear the expected signs and have a significant positive relationship with economic growth (see Table 3). Similar estimation results are also obtained for the dataset that corresponds to the developed economies, albeit FDI flows become insignificant (Table 4). Furthermore, the evidence generated for the developing economies suggest that apart from the gross capital formation and human capital variables, government stability is also found to have a positive relationship with economic growth (Table 5).

\section{Concluding remarks}

This paper empirically reveals a new perspective regarding the role of the strength of patent legislation and patent enforcement in stimulating economic development during the post-TRIPs years and raises important considerations regarding future policy making activities promoting stronger patent systems. In recent decades, a series of lengthy policy negotiations between developed and developing countries have been held, aimed at reducing trade barriers and increasing international business activity and higher rates of economic growth. One of the institutional contexts requiring reforms commonly included in multilateral negotiations relates to the strengthening of patent systems, with the most significant milestone being set with the signing of the TRIPs agreement in 1994. Many previous studies have investigated the effect of patent legislation levels in the years prior to or immediately after the TRIPs agreement, finding strengthening levels of patent legislation to have a positive effect on a country's economic growth. The study reported here contributes to the existing literature by investigating:

a the longer term impact of strengthening patent legislation after TRIPs for the years 1998-2011

b for the first time, the effect of patent enforcement on the economic development of countries.

The results indicate that for the 42 countries studied strengthened levels of patent legislation in the years after TRIPs have had a negative effect on economic growth of the countries in our sample. The results challenge the conventional wisdom that strengthening the patent related legislative framework has beneficial economic outcomes for the reforming countries. This is because the global context of patent protection legislation has experienced drastic changes during the implementation of the TRIPs requirement. Prior to TRIPs, countries (mainly developed) reformed and strengthened their patent systems on an ad-hoc basis. After TRIPs, patent regulations changed in a uniform and speedy manner. Any positive effects in terms of becoming more attractive investment destinations compared to other countries disappeared. Especially in developed economies, MNEs were able to extend their patent protection in international markets in a monopolistic (at times) manner, making it more difficult for other companies to compete in an industry. A characteristic example of this behaviour is the patent wars in the telecommunications industry which discourage new and existing companies to compete 
in the market for fear of being sued and entering a lengthy legal battle over patent infringement. The results raise strong concerns regarding the continued emphasis in strengthening levels of patent legislation since the effect may be positive for strong global MNEs, while the effect on the overall economy may be negative. This is especially the case for developing countries that are the recipients of strong diplomatic pressures and, at the same time, are the ones where the national economic concerns tend to be stronger.

In contrast, strengthening levels of patent enforcement have a positive effect on economic development and this is particularly the case for the developing countries in the sample. The effect of stronger enforcement on the growth of developed economies is however negative, as this often relates to the even more rigid and inflexible legislative frameworks that have evolved in developed economies in the years after the TRIPs agreement. This is the first empirical study of the role of patent enforcement in stimulating economic growth. The results are aligned with the shift in the attention of policy negotiations in recent years whereby some countries are now pushing for the adoption of stronger levels of patent enforcement by developing countries rather than focusing on the adoption of stronger laws per se. Furthermore, the results provide policy makers with a clear indication that such reforms can benefit the developing countries adopting them. However, it is important to highlight that while the results concerning the role of patent enforcement provide a positive outlook, policy makers should be cognisant that these results relate to a time period (1998-2011) when the changes in the institutional contexts of countries mainly focused on the existence of patent legislation rather than patent enforcement. If policy makers push for the adoption of patent enforcement on a widespread TRIPs style scale, the implications may have negative effects on longer term economic development across some countries. This is unlikely to be an attractive proposition for countries, particularly those at the lower end of the economic development scale.

\section{References}

Arora, A. (2009) 'Intellectual property rights and the international transfer of technology: setting out an agenda for empirical research in developing countries', in World Intellectual Property Organization (WIPO) (Eds.): The Economics of Intellectual Property: Suggestions for Further Research in Developing Countries and Countries with Economies in Transition, WIPO publication no. 1012(E) , pp.41-58, Geneva.

Awokuse, T.O. and Yin, H. (2010) 'Does stronger intellectual property rights protection induce more bilateral trade? Evidence from China's imports', World Development, Vol. 38, No. 8, pp.1094-1104.

Baltagi, B.H. (2013) Econometric Analysis of Panel Data, Wiley, Chichester.

Barro, R.J. (1991) 'Economic growth in a cross section of countries', Quarterly Journal of Economics, Vol. 106, No. 2, pp.407-443.

Barro, R.J. (2003) 'Determinants of economic growth in a panel of countries', Annals of Economics and Finance, Vol. 4, No. 2, pp.231-274.

Borensztein, E., de Gregorio, J. and Lee, J.W. (1998) 'How does foreign direct investment affect economic growth?', Journal of international Economics, Vol. 45, No. 1, pp.115-135.

Ceccagnoli, M. (2006) 'Appropriability, preemption, and firm performance', Strategic Management Journal, Vol. 30, No. 1, pp.81-98. 
Davidson, R. and MacKinnon, J.G. (1993) Estimation and Inference in Econometrics, Oxford University Press, New York.

Falvey, R.E., Foster, N. and Greenaway, D. (2006) 'Intellectual property rights and economic growth', Review of Development Economics, Vol. 10, No. 4, pp.700-719.

Ginarte, J.C. and Park, W. (1997) 'Determinants of patent rights: a cross-national study', Research Policy, Vol. 26, No. 3, pp.283-301.

Gould, D.M. and Gruben, W.C. (1996) 'The role of intellectual property rights in economic growth', Journal of Development Economics, Vol. 48, No. 2, pp.323-350.

Hall, B.H. and Harhoff, D. (2012) 'Recent research on the economics of patents', Annual Review of Economics, Vol. 4, No. 1, pp.541-565.

Hargreaves, I. (2011) Digital Opportunity: A Review of Intellectual Property and Growth [online] http://www.ipo.gov.uk/ipreview-finalreport.pdf (accessed 24 May 2014).

Kim, Y.K., Lee, K., Park, W.G. and Choo, K. (2012) 'Appropriate intellectual property protection and economic growth in countries at different levels of development', Research Policy, Vol. 41, No. 2, pp.358-375.

Kumar, N. (1996) 'Intellectual property protection, market orientation and location of overseas R\&D activities by multinational enterprises', World Development, Vol. 24, No. 4, pp.673-688.

Kutner, M.H., Nachtsheim, C. and Neter, J. (2004) Applied Linear Regression Models, McGraw-Hill/Irwin, New York.

Li, X. and Liu, X. (2005) 'Foreign direct investment and economic growth: an increasingly endogenous relationship', World Development, Vol. 33, No. 3, pp.393-407.

Lipsey, R.E. (2002) Home and Host Country Effects of FDI, NBER Working Paper 9293, Cambridge, MA.

Mankiw, N.G., Romer, D. and Weil, D.N. (1992) 'A contribution to the empirics of economic growth', The Quarterly Journal of Economics, Vol. 107, No. 2, pp.407-437.

Maskus, K.E. (2000) Intellectual Property Rights in the Global Economy, Institute for International Economics, Washington DC.

Mazzoleni, R. and Nelson, R.R. (1998) 'The benefits and costs of strong patent protection: a contribution to the current debate', Research Policy, Vol. 27, No. 3, pp.273-284.

O’Brien, R.M. (2007) 'A caution regarding rules of thumb for variance inflation factors', Quality \& Quantity, Vol. 41, No. 5, pp.673-690.

Papageorgiadis, N., Cross, A.R. and Alexiou, C. (2013) 'The impact of the institution of patent protection and enforcement on entry mode strategy: a panel data investigation of U.S. firms', International Business Review, Vol. 22, No. 1, pp.278-292.

Papageorgiadis, N., Cross, A.R. and Alexiou, C. (2014) 'International patent systems strength 1998-2011', Journal of World Business, Vol. 50, No. 2, Forthcoming.

Park, W. (2008) 'International patent protection 1960-2005', Research Policy, Vol. 37, No. 4, pp.761-766.

Park, W. and Ginarte, C. (1997) 'Intellectual property rights and economic growth', Contemporary Economic Policy, Vol. 15, No. 3, pp.51-61.

PRS Group (2013) International Country Risk Guide [online] http://www.adbi.org/3rdpartycdrom/ 2004/12/01/1359.international.country.risk/ (accessed 13 March 2014).

Reichman, J.H. and Dreyfuss, R.C. (2007) 'Harmonization without consensus: critical reflections on drafting a substantive patent law treaty', Duke Law Journal, Vol. 57, No. 1, pp.85-130.

Sala-i-Martin, X.X. (1997) 'I just ran two million regressions', The American Economic Review, Vol. 87, No. 2, pp.178-183.

Schneider, P.H. (2005) 'International trade, economic growth and intellectual property rights: a panel data study of developed and developing countries', Journal of Development Economics, Vol. 78, No. 2, pp.529-547. 
Stiglitz, J.E. (2008) 'Economic foundations of intellectual property rights', Duke Law Journal, Vol. 57, No. 6, pp.1693-1724.

Teece, D.J. (1986) 'Profiting from technological innovation: implications for integration, collaboration and licensing and public policy', Research Policy, Vol. 15, No. 6, pp.285-305.

Taubman, A., Wager, H. and Watal, J. (Eds.) (2012) A Handbook on the WTO TRIPs Agreement, Cambridge University Press, Cambridge.

Thompson, M.A. and Rushing, F.W. (1996) 'An empirical analysis of the impact of patent protection on economic growth', Journal of Economic Development, Vol. 21, No. 2, pp.61-79.

Thompson, M.A. and Rushing, F.W. (1999) 'An empirical analysis of the impact of patent protection on economic growth: an extension', Journal of Economic Development, Vol. 24, No. 1, pp.67-76.

United Nations Conference of Trade and Development (UNCTAD) (1996) The TRIPs Agreement and Developing Countries, UNCTAD/ITE/1, United Nations, New York and Geneva.

World Bank (1989). Sub-Saharan Africa, from Crisis to Sustainable Growth: A Long-Term Perspective Study [online] http://econ.worldbank.org/external $/$ default $/$ main?pagePK= 64165259\& theSitePK=477894\&piPK=64165421\&menuPK=64166093\&entityID=000178830 _98101901364149 (accessed 20 September 2014).

World Bank (2009) How We Classify Countries [online] http://data.worldbank.org/about/countryclassifications (accessed 20 September 2014).

World Bank (2014a) Glossary [online] http://www.worldbank.org/depweb/english/beyond/ global/glossary.html (accessed 20 September 2014).

World Bank (2014b) World Bank Open Data [online] http://data.worldbank.org (accessed 20 September 2014).

World Bank (2014c) School Enrolment, Tertiary (\% gross) [online] http://data.worldbank.org/ indicator/SE.TER.ENRR (accessed 20 September 2014).

World Intellectual Property Organization (WIPO) (2014) What is a Patent?, WIPO publication no. L450PA/E, Geneva.

World Trade Organization (WTO) (2013) Responding to Least Developed Countries' Special Needs in Intellectual Property [online] http://www.wto.org/english/tratop_e/trips_e/ldc_e.htm (accessed 18 March 2014).

Yang, D. and Sonmez, M. (2013) 'Integration and divergence of patent systems across national and international institutions', Journal of World Business, Vol. 48, No. 4, pp.527-538.

Ziedonis, R.H. (2003) 'Patent litigation in the US semiconductor industry', in Cohen, W.M. and Merrill, S.A. (Eds.): Patents in the Knowledge Based Economy, pp.180-216, The National Academies Press, Washington, DC.

\section{Notes}

1 The World Bank (2014a) defines economic development as a "qualitative change and restructuring in a country's economy in connection with technological and social progress".

2 Covering the period 1998-2011.

3 The World Bank (2009) classification was used for this categorization. This is based on gross national income (GNI) per capita data. Developed countries are those with a GNI per capita figure in excess of $\$ 11,905$. Countries with a smaller figure (i.e., low income, lower middle income and upper middle income countries) are considered collectively to be developing countries.

4 While the Papageorgiadis et al. (2014) index provides data for 48 countries, the usable data for the timeframe considered in this study was restricted to 42 countries only.

5 The cross correlation matrix is not presented due to space limitations, however it can be provided on request. 